\title{
Renin Release during Acute Reduction of Arterial Pressure in Normotensive Subjects and Patients with Renovascular Hypertension *
}

\author{
Yoshiniro Kaneko, $\uparrow$ Takao Ikeda, Tadanao Takeda, and Hideo Ueda \\ (From the Second Department of Internal Medicine, Faculty of Medicine, University of \\ Tokyo, Tokyo, Japan)
}

\begin{abstract}
Summary. In normotensive subjects, acute reduction of mean arterial pressure to from 60 to $75 \mathrm{~mm} \mathrm{Hg}$ by infusion of sodium nitroprusside caused significant increase in renin activity of renal venous plasma and also in the renalsystemic difference of renin activity. At the same time, the products of the renal-systemic difference of renin activity and renal plasma flow increased significantly, whereas renin substrate activity of plasma was unchanged, indicating that there was an increase in renin release during reduction in pressure. Renin activity of renal venous plasma, expressed in logarithms, showed a significant correlation with the degree of reduction in pressure; an increase in renin activity became significant when mean arterial pressure was reduced to below a level of 70 to $75 \mathrm{~mm} \mathrm{Hg}$.

There was a striking difference in the renal response to reduction in pressure between patients with renovascular hypertension and normotensive subjects. In 10 renovascular hypertensive patients, significant increase in renin release occurred from the involved kidney at mean arterial pressures ranging from 90 to $137 \mathrm{~mm} \mathrm{Hg}$; the threshold at which renin release increased was shifted to a range much higher than that in normotensive subjects. Furthermore, the magnitude of renin release from the involved kidney was significantly greater when compared to that in normotensive subjects. In contrast, in the contralateral uninvolved kidney, no significant release of renin was detected during reduction in pressure. The renal mechanism controlling renin secretion appears to be operative at higher systemic arterial pressure levels and with enhanced responsiveness in the involved kidney of renovascular hypertensive patients; the findings are consistent with the hypothesis that the renin-angiotensin system participates in maintaining hypertension in this disease.
\end{abstract}

\section{Introduction}

Recently, Skinner, McCubbin, and Page $(1,2)$ showed that reduction in mean renal perfusion pressure causes the kidney to increase renin se-

* Submitted for publication September 16, 1966; accepted January 4, 1967.

This study was supported in part by U. S. Public Health Service research grant HE 09060 from the National Heart Institute.

A preliminary report was presented at the Twentythird Meeting of the International Congress of Physiological Sciences, Tokyo, September 8, 1965. cretion in normotensive and hypertensive dogs and suggested that the renal mechanism controlling renin secretion may be a homeostatic one that participates in control of normal arterial pressure and that its dysfunction might be involved in the genesis and maintenance of renal hypertension. It is as yet unknown, however, whether the human kidney can similarly increase renin secretion in response to reduction in pressure and whether

† Address requests for reprints to Dr. Yoshihiro Kaneko, Second Department of Internal Medicine, Tokyo University Hospital, Hongo 7, Bunkyo-ku, Tokyo, Japan. 
there is any change in this renal mechanism in human hypertensive patients. The present investigation examines the effect of acute reduction of arterial pressure on renin release in normotensive subjects and in patients with renovascular hypertension.

\section{Methods \\ Clinical material and procedure}

Studies were performed on hospitalized normotensive and renovascular hypertensive patients on a normal diet. Normotensive patients, four women and nine men ranging in age from 19 to 47 years, showed no evidence of significant cardiovascular disease, and their arterial blood pressures ranged from 111/70 (average mean arterial blood pressure, 84) to $140 / 83 \mathrm{~mm} \mathrm{Hg}$ (average mean, 102) at the time of the study. Patients with renovascular hypertension consisted of six women and four men ranging in age from 16 to 53 years, and their arterial pressures ranged from 150/78 (average mean, 102) to $225 / 151 \mathrm{~mm} \mathrm{Hg}$ (average mean, 176). Clinical findings are shown in Table I. The diagnosis of renovascular hypertension was established by demonstration of severe stenotic lesions of the main renal artery by aortography and of an ischemic pattern in split renal function studies (Howard or Rapoport test), except in one patient who had segmental ischemia due to severe stenosis of one of the double main renal arteries and showed a negative split function test and another from whom urine was not collected. In six patients, the diagnosis was confirmed later by reduction of arterial pressure after surgical treatment (Table I). Eight patients had unilateral and one patient bilateral renal arterial stenosis. One patient had severe stenosis on one side and slight stenosis on the other. None showed clinical evidence of heart or renal failure.

The purpose and procedures of the study were explained to all subjects, and their free consent was obtained. All medications except for small amounts of sedatives had been discontinued at least 2 weeks before study, and the patients were fasting and supine at the time of measurements performed in the afternoon. To collect renal venous blood, we introduced a polyethylene catheter (KIFA red-1) into a femoral vein with the patient under local anesthesia and advanced it under fluoroscopic control into a renal vein of normotensive subjects or into the vein of the involved kidney of patients with renovascular hypertension. Position of the catheter was confirmed by observing extraction of $p$-aminohippurate. In some patients, two catheters were introduced into both femoral veins and passed into the bilateral renal veins at the same time. Systemic venous blood was collected from a vein of one arm or leg. Brachial arterial blood pressure was measured by auscultation every 2 or 3 minutes along with heart rate, and mean arterial pressure (diastolic plus one-third of pulse pressure) was calculated. To lower systemic arterial pressure, we infused sodium nitroprusside, dissolved in physiologic saline in concentrations of
100 to $150 \mu \mathrm{g}$ per $\mathrm{ml}$, into a vein of one arm or leg at a rate of 30 to $240 \mu \mathrm{g}$ per minute. Sodium nitroprusside is known to exert its depressor effect by direct action on vascular smooth muscle (3).

Control samples of renal and systemic venous blood were collected from the patients after they had rested at least 30 minutes in the supine position. Thereafter, mean arterial pressure was reduced progressively, by infusion of sodium nitroprusside, from 10 to $37 \mathrm{~mm} \mathrm{Hg}$ in normotensive subjects and 11 to $55 \mathrm{~mm} \mathrm{Hg}$ in patients with renovascular hypertension, and repeated samplings of renal and systemic venous blood were made when arterial pressure had been stabilized for 10 to $15 \mathrm{~min}$ utes. If symptoms of cerebral ischemia such as yawning appeared, the rate of infusion was decreased until the symptoms disappeared; there were no serious reactions in any subjects tested. In some patients, samplings were repeated when arterial pressure had returned to almost the preinfusion level after termination of the infusion.

\section{Assay of plasma renin activity}

The procedure used for determination of renin activity of plasma was based on methods of Skinner and associates (1) and Helmer and Judson (4) and on the principle that the sensitivity of renin measurement can be increased by prolonging the time of incubation (5).

Approximately $8 \mathrm{ml}$ of renal and systemic venous blood was collected simultaneously in polyethylene test tubes and mixed with EDTA $\left(2 \times 10^{-3} \mathrm{M}\right)$ to inhibit angiotensinase (6) and with heparin (5 to $10 \mathrm{U}$ per $\mathrm{ml}$ blood) as an additional safeguard against coagulation. The tubes were placed in an ice bath, the blood samples were centrifuged at $5,000 \mathrm{rpm}$ for 10 minutes at below $4^{\circ} \mathrm{C}$, and the separated plasma was kept frozen. The next morning, each plasma sample was adjusted to $\mathrm{pH} 5.5$ with $0.2 \mathrm{~N} \mathrm{HCl}$ and divided into three 1-ml portions. One portion was diluted with $0.5 \mathrm{ml}$ of physiologic saline and immediately boiled for 10 minutes. To each of the other two portions was added one drop of $0.5 \%$ neomycin sulfate to protect against possible bacterial contamination (7). To one of the two portions we added two drops of $0.1 \%$ diisopropyl fluorophosphate (DFP) as a further precaution against angiotensinase, according to Pickens and his co-workers (5). The two portions were then incubated for 24 hours at $37^{\circ} \mathrm{C}$ without agitation and thereafter diluted with $0.5 \mathrm{ml}$ of saline and boiled for $15 \mathrm{~min}$ utes in a chamber with a draft. The supernatant was separated by centrifugation at $5,000 \mathrm{rpm}$ for 10 minutes.

The supernatant samples were assayed for pressor activity in $180-$ to $300-\mathrm{g}$ male rats treated at least $1 \frac{1}{2}$ hours before with intraperitoneal sodium pentobarbital ( $5 \mathrm{mg}$ per $100 \mathrm{~g}$ as an initial dose and 1 to $0.5 \mathrm{mg}$ per $100 \mathrm{~g}$ as supplemental doses) and pentolinium tartrate (2 mg per $100 \mathrm{~g}$ initally and $0.4 \mathrm{mg}$ per $100 \mathrm{~g}$ supplementally). Mean arterial pressure was measured from a cannulated carotid artery and recorded on a direct writing oscillograph. The supernatant samples from the three portions were injected into a femoral vein in volumes of 0.1 to 0.3 (usually 0.2 ) $\mathrm{ml}$. The unincubated sample gave only a slight rise or no measurable change 


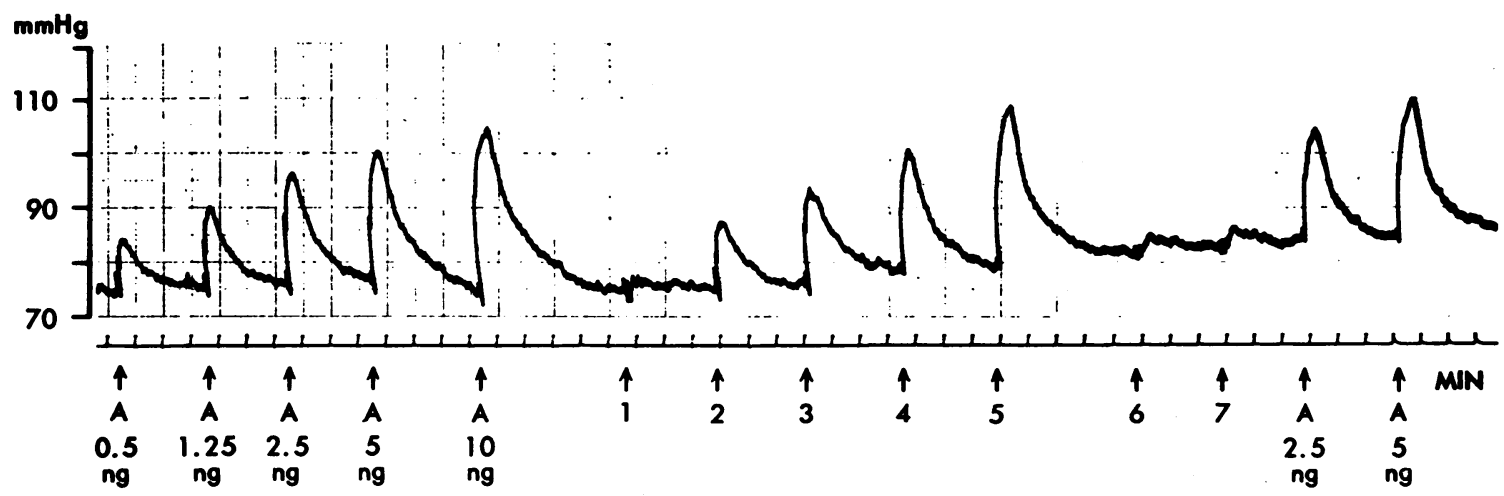

Fig. 1. Tracing from assay of plasma renin activity on rat. A indicates standard synthetic angiotensin. 1 to 7 indicate plasma from a patient with renovascular hypertension $(0.1 \mathrm{ml}$ of the supernatant). 2 and 3 represent incubated systemic and renal (involved side) venous plasma collected simultaneously during the control period, and 4 and 5 incubated systemic and renal venous plasma collected during reduction in arterial pressure. 1, 6, and 7 are unincubated counterparts of 3,4 , and 5 , respectively.

in pressure; the other two incubated samples served to confirm the pressor activity generated by incubation (Figure 1). Under usual conditions, addition of DFP did not produce significant change in the pressor activity generated in plasma. A series of synthetic angiotensin solutions ${ }^{1}$ were injected at frequent intervals and served as standards for measuring pressor activity of the test samples (Figure 1). Pressor activity generated in plasma as a result of 24-hour incubation was determined, expressed in terms of nanograms angiotensin equivalent per milliliter of the original plasma, and designated as plasma renin activity.

\section{Evidence that the substances assayed are renin and angio- tensin}

Incubated renal venous plasma collected during the experimental period demonstrated greater pressor activity than incubated systemic venous plasma (Figure 1). Incubated renal and systemic venous plasma showed much greater pressor activity than their unincubated counterparts (Figure 1). The pressor response to incubated plasma was identical to that produced by synthetic angiotensin (Figure 1). In control experiments, pressor activity of the supernatant of incubated active plasma was heat stable, was destroyed by incubation with chymotrypsin or trypsin, and disappeared after 24-hour dialysis. The mobility of the pressor substance in the supernatant of incubated plasma on Whatman no. 1 paper chromatography at $\mathrm{pH} 2.1$ was tested; ${ }^{2}$ it was similar to that of synthetic angiotensin. To determine the optimal $\mathrm{pH}$ in the reaction, we incubated three samples of active plasma (EDTA and DFP added) at $37^{\circ} \mathrm{C}$ for 24 hours at $\mathrm{pH} 4.5$ to 7.5 and assayed them on the rat. The average pressor activity generated after incubation at $\mathrm{pH}$ $4.5,5.0,5.5,6.0,6.5,7.0$, and 7.5 was $7,63,148,117,64$,

1 Valyl-5 octapeptide, Ciba Pharmaceutical Co., Summit, N. J.

2 In collaboration with Dr. Y. Takabatake.
14 , and $7 \mathrm{ng}$ per $\mathrm{ml}$, respectively ; the activity was great-

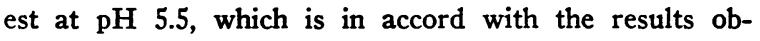
tained by others $(4,5)$.

\section{Examinations of the assay method}

Effect of heparin. Since heparin used as an anticoagulant might affect angiotensin formation in incubated plasma, its effect was checked. Heparin was added to three samples of active plasma that had been collected without it in concentrations of $0,5,10,20,40,100,200$, and $400 \mathrm{U}$ per $\mathrm{ml}$, and the samples were incubated in the presence of EDTA and DFP for 24 hours at $\mathrm{pH}$ 5.5. In concentrations below $40 \mathrm{U}$ per $\mathrm{ml}$, addition of heparin did not produce significant change in the pressor activity generated in plasma, and, in concentrations of 100,200 , and $400 \mathrm{U}$ per $\mathrm{ml}$, the average pressor activity decreased to 89,78 , and $64 \%$ of the control, respectively. The effect of the doses of heparin used in the present method was considered insignificant.

Angiotensin formation during incubation and renin substrate activity of plasma. Each of four samples of active plasma was incubated for $4,8,14,20$, and 24 hours. Angiotensin produced in plasma was roughly proportional to the length of incubation time when the yield was below $400 \mathrm{ng}$ per $\mathrm{ml}$. In plasma of higher renin activity, the reaction was slowed considerably (Figure 2). Since plasma renin activity measured by our method is below $400 \mathrm{ng}$ per $\mathrm{ml}$ under usual conditions, renin substrate concentration in the reaction system was usually considered excessive for 24 hours of incubation.

Human renin solution was prepared from cadaver kidneys by the method of Haas and Goldblatt ( 8$), 3$ and renin substrate activity of plasma was assayed in five normotensive subjects and four patients with renovascular hypertension. To $0.5 \mathrm{ml}$ plasma were added $0.2 \mathrm{ml}$ of $0.01 \mathrm{M}$ EDTA, $0.1 \mathrm{ml}$ of diluted human renin solution, and $0.3 \mathrm{ml}$ saline. After $\mathrm{pH}$ adjustment to 5.5, 1 drop of

${ }^{3}$ In collaboration with Drs. M. Ishii and H. Tagawa. 
TABLE I

Clinical data on 10 patients with renovascular hypertension*

\begin{tabular}{|c|c|c|c|c|c|c|c|c|c|c|}
\hline Patient & Age & Sex & $\underset{\text { BP }}{\text { Admission }}$ & $\begin{array}{c}\text { Known } \\
\text { dura- } \\
\text { tion of } \\
\text { hyper- } \\
\text { tension }\end{array}$ & $\begin{array}{l}\text { Ocular } \\
\text { fundi }\end{array}$ & BUN & RBF & $\begin{array}{c}\text { Howard } \dagger \\
\text { or } \\
\text { Rapoport } \ddagger \\
\text { test }\end{array}$ & $\begin{array}{l}\text { Aortog- } \\
\text { raphy } \\
\text { (site of } \\
\text { renal } \\
\text { arterial } \\
\text { stenosis) }\end{array}$ & Remarks \\
\hline & years & & $m m H g$ & years & grade§ & $\begin{array}{l}\mathrm{mg} / \\
100 \\
\mathrm{ml}\end{array}$ & $m l / m i n$ & & & \\
\hline S.U. & 38 & $\mathbf{M}$ & $260 / 150$ & 2.5 & 1 & 17 & 740 & + & Bilateral & Had surgery. Postoperative BP, 134/84 \\
\hline H.I. & 23 & $\mathbf{M}$ & $186 / 124$ & 0.5 & 1 & 13 & 736 & + & Right & Died at surgery. \\
\hline A.K. & 27 & $\mathbf{F}$ & $240 / 130$ & 2 & 2 & 15 & 700 & + & Right & Had surgery. Postoperative BP, 134/92. \\
\hline H.I. & 23 & $\mathbf{F}$ & $220 / 130$ & 0.5 & 1 & 13 & 656 & + & Right & Had surgery. Postoperative BP, 128/80. \\
\hline A.O. & 29 & $\mathbf{M}$ & $250 / 126$ & 1 & 1 & 14 & 1,140 & + & Left & Surgery was not done. \\
\hline R.S. & 53 & $\mathbf{M}$ & $210 / 120$ & 1.5 & 2 & 16 & 547 & + & Left\| & Had surgery. Postoperative BP, 130/80. \\
\hline A.U. & 16 & $\mathbf{F}$ & $220 / 116$ & 1 & 4 & 13 & 652 & + & Right $\llbracket$ & Had surgery. Postoperative BP, 160/94. \\
\hline K.M. & 28 & $\mathbf{F}$ & $180 / 120$ & 8 & 2 & 18 & 921 & + & Left & Had surgery. Postoperative BP, 124/84. \\
\hline K.T. & 29 & $\mathbf{F}$ & $164 / 90$ & 3 & 1 & 11 & 1,180 & Failed & Right & Surgery is pending. \\
\hline N.G. & 19 & F & $170 / 100$ & 2.5 & 1 & 12 & 963 & + & Right & Surgery is pending. \\
\hline
\end{tabular}

* Abbreviations: $\mathrm{BP}=$ blood pressure $\mathrm{BUN}=$ blood urea nitrogen; $\mathrm{RBF}=$ renal blood flow measured by $p$-aminohippurate clearance.

$*$ Abbreviations : $\mathrm{BP}=$ blood pressure; $\mathrm{BUN}=$ blood urea nitrogen; $\mathrm{RBF}=$ renal blood flow measured by $p$-aminohippurate clearance.
$\dagger$ The test was considered positive when the affected side showed reductions of $50 \%$ or more in urine flow and $15 \%$ or more in the sodium concentration compared to the unaffected or less affected side.

† The test was considered positive when the tubular rejection fraction ratio was below 0.6 or above 1.6.

Keith-Wagener classification.

Severe stenosis of left main renal artery with slight stenosis of right main renal artery.

$0.1 \%$ DFP and 1 drop of $0.5 \%$ neomycin sulfate were added. The mixture was incubated for 24 hours at $37^{\circ} \mathrm{C}$ and thereafter diluted with $2 \mathrm{ml}$ of saline and boiled for 15 minutes. The separated supernatant was assayed for pressor activity, and substrate activity was expressed as nanograms angiotensin produced per $1 \mathrm{ml}$ plasma. Plasma substrate activity measured by this method ranged from 470 to $800 \mathrm{ng}$ per $\mathrm{ml}$ in normotensive subjects.

Recovery. Human crude angiotensin was produced by

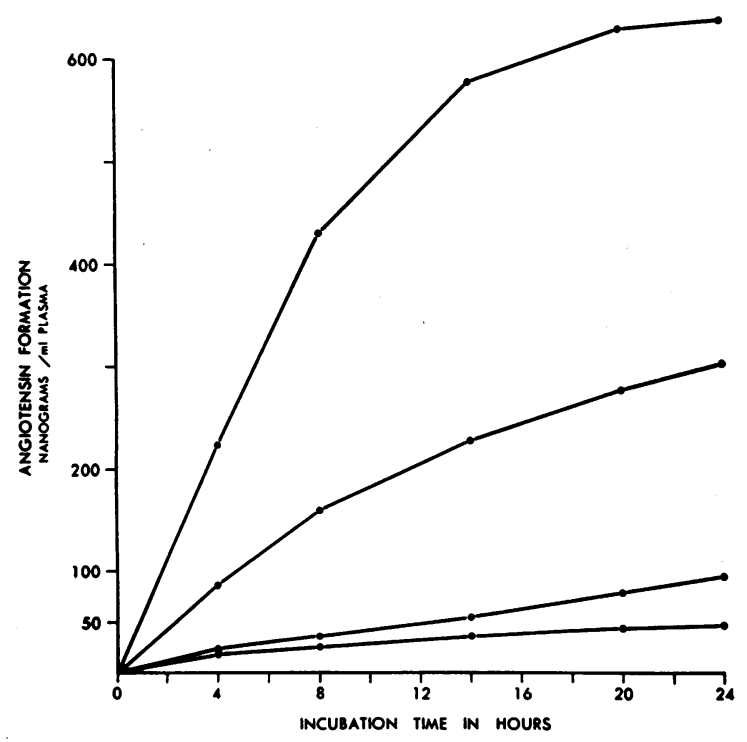

Fig. 2. ANgiotensin FORMation DURING 24-HOUR INCUBATION. The upper two curves were obtained from plasma incubated with human renin and the lower ones from active plasma of patients. See text. incubation of human renin with human plasma. Possible loss of angiotensin by the remaining angiotensinase in the reaction system was determined by adding human angiotensin in doses of about 10 to $400 \mathrm{ng}$ to $1 \mathrm{ml}$ of plasma and carrying through the complete procedure. In eight experiments, the recovery after a 24-hour incubation ranged from 70 to $92 \%$, mean $83 \%$.

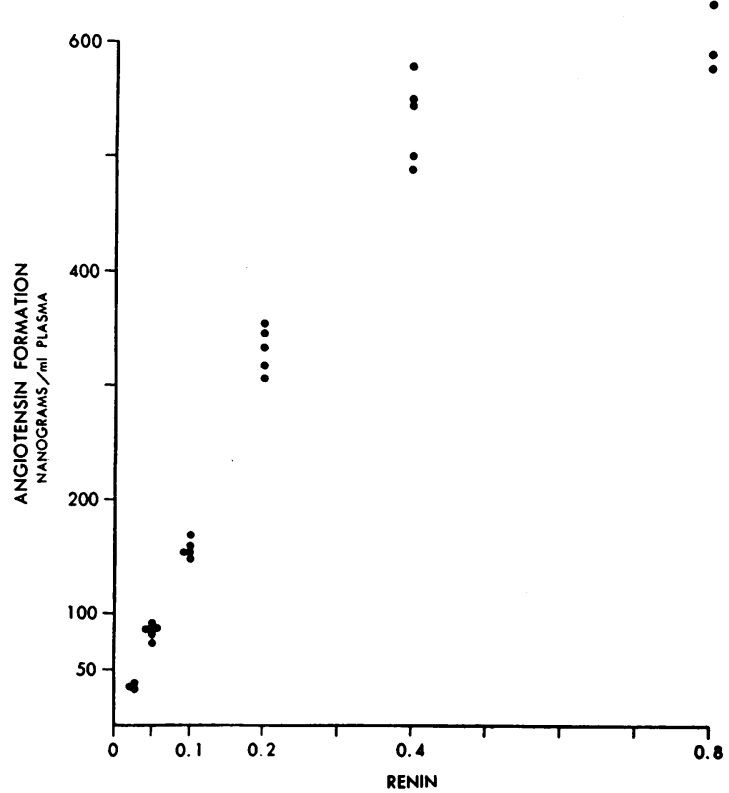

Fig. 3. ANgiotensin yield After incubation AND THE AMOUNT OF RENIN ADDED. Human renin in milliliters of diluted solution was added to $1 \mathrm{ml}$ of plasma and incubated for 24 hours. See text. 
Various amounts of human renin were added to $1 \mathrm{ml}$ of human plasma and incubated for 24 hours. The angiotensin yield after incubation was proportional to the amount of renin added when the yield was below $400 \mathrm{ng}$ per $\mathrm{ml}$ (Figure 3 ); the mean recovery was $98 \pm 9.7$ (SD) $\%$ in those samples.

Sensitivity and reproducibility. The lower limit of sensitivity of this method varied according to the assay rats. Usually 0.2 to $0.5 \mathrm{ng}$ of standard angiotensin gave a measurable rise, and plasma renin activity of 1 to $2 \mathrm{ng}$ per $\mathrm{ml}$ or more was detected.

Renin activity of 50 different plasma samples was measured in duplicate; the average difference between paired measurements was $14.7 \pm 10.7$ (SD) \%. A difference in renin activity between individual plasma samples was considered significant when it exceeded $14.7 \pm 21.3$ (2 SD) or $36 \%$ and also $5 \mathrm{ng}$ per $\mathrm{ml}$.

Statistical analyses. In all experiments, the differences between the means were tested by Student's $t$ test (9).

\section{Results}

Renin activity in plasma of normotensive subjects and renovascular hypertensive patients during control period. Renin activity of renal venous plasma of 13 normotensive subjects ranged from 4 to $14 \mathrm{ng}$ per $\mathrm{ml}$ in the control period, with a mean of $8.1 \pm 0.8(\mathrm{SE})$; that of systemic venous plasma ranged from 3 to $10 \mathrm{ng}$ per $\mathrm{ml}$, with a mean of $6.4 \pm 0.6$. The difference in renin activity between renal and systemic venous plasma ranged from 0 to $5 \mathrm{ng}$ per $\mathrm{ml}$, mean $1.7 \pm 0.5$ (Table II). The normal ranges of renin activity of renal and systemic venous plasma calculated by the present method were considered to be $8.1 \pm$ 5.6 (2 SD) and $6.4 \pm 4.6$ (2 SD) ng per $\mathrm{ml}$, respectively.

Renin activity of venous plasma from the involved kidneys of 10 renovascular hypertensive patients (Table IV) ranged from 5 to $76 \mathrm{ng}$ per $\mathrm{ml}$, with a mean of $40.4 \pm 8.0$; the value was elevated beyond the normal range in 8 of the $10 \mathrm{pa}-$ tients. Renin activity of systemic venous plasma ranged from 4 to $55 \mathrm{ng}$ per $\mathrm{ml}$, with a mean of $21.7 \pm 5.2$; elevated activity was found in 7 patients. The difference in mean renin activity between the normotensive and renovascular hypertensive groups was significant both with renal $(p<0.001)$ and with systemic $(p<0.005)$ venous plasma. The difference in renin activity between renal and systemic venous plasmas in the renovascular hypertensive group ranged from 1 to $48 \mathrm{ng}$ per $\mathrm{ml}$, with a mean of $18.7 \pm 5.3$, which

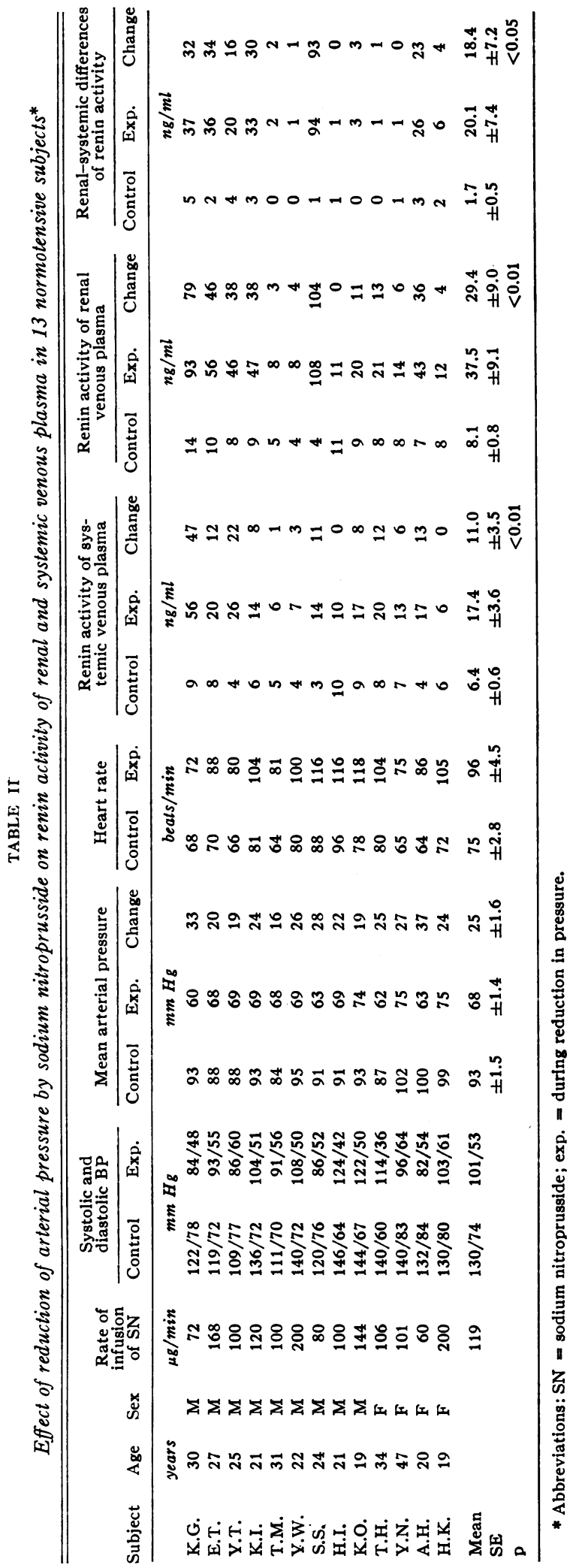


was significantly $(p<0.005)$ greater than that in the normotensive group.

Effect of reduction of arterial pressure on renin activity in plasma of normotensive subjects. After control samplings of renal and systemic venous blood were made, graded doses of sodium nitroprusside were infused into 13 normotensive subjects. Mean arterial pressure was reduced progressively by from 10 to $37 \mathrm{~mm} \mathrm{Hg}$ in 1 to 3 steps, and samplings were repeated during each hypotensive period. Reduction of mean arterial pressure to 60 to $75 \mathrm{~mm} \mathrm{Hg}$ caused significant increase of renin activity in renal venous plasma in 8 subjects and no significant change in 5 ; above $75 \mathrm{~mm} \mathrm{Hg}$, no subjects showed significant change in renin activity. Table II shows the results obtained during reduction in pressure to 60 to 75 $\mathrm{mm} \mathrm{Hg}$ in 13 subjects, and Figure 4 illustrates a typical example of the response to reduction in pressure. On the average, renin activity of renal venous plasma increased from 8.1 to $37.5 \mathrm{ng}$ per $\mathrm{ml}$ when arterial pressure decreased from 93 to 68 $\mathrm{mm} \mathrm{Hg}$; the increase was significant $(\mathrm{p}<0.01)$. The increase in renin activity of renal venous

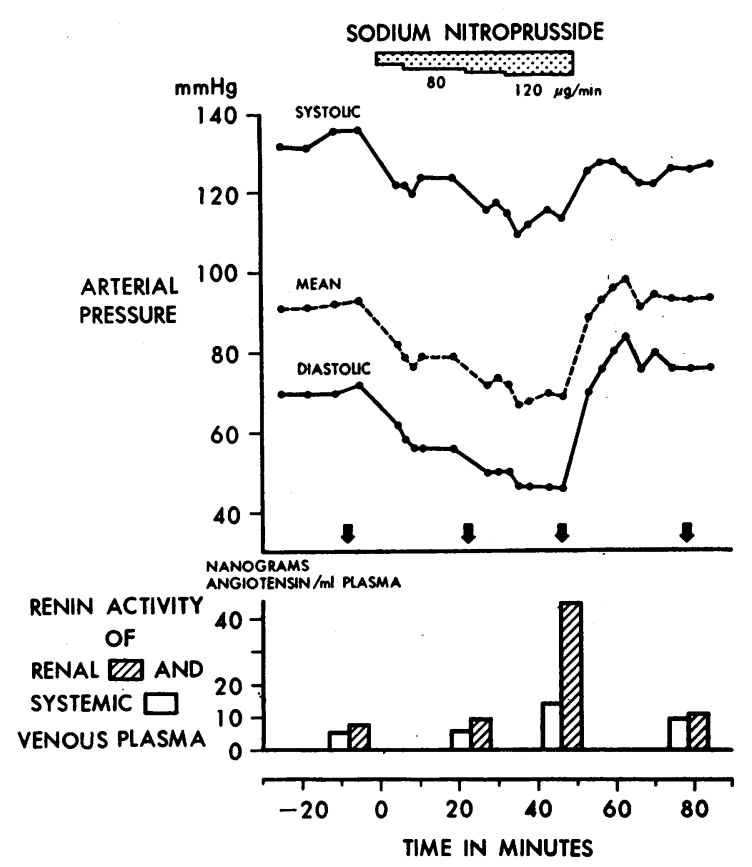

Fig. 4. EFFect OF REDUCTION OF ARTERIAL PRESSURE BY SODIUM NITROPRUSSIDE ON RENIN ACTIVITY OF RENAL AND SYSTEMIC VENOUS PLASMA IN A 21-YEAR-OLD NORMOTENSIVE SUBJECT. Renin activity was unchanged at mean arterial pressure of $79 \mathrm{~mm} \mathrm{Hg}$ but increased at $69 \mathrm{~mm} \mathrm{Hg}$. plasma was accompanied by one in systemic venous plasma, which was significant but less in magnitude. The renal-systemic difference in renin activity increased in 6 of the 13 subjects; the mean difference increased from 1.7 to $20.1 \mathrm{ng}$ per $\mathrm{ml}$ $(\mathrm{p}<0.05$, Table II).

The increase in renal venous renin activity was detected after 10 to 15 minutes of reduction in mean arterial pressure to below $75 \mathrm{~mm} \mathrm{Hg}$. It persisted for the hypotensive period and then returned almost to the control value 15 to $30 \mathrm{~min}$ utes after arterial pressure recovered to near the preinfusion level (Figure 4). The return of systemic venous renin activity was delayed compared to that of renal venous renin activity. In control observations, renin activity was measured several times without reduction in pressure, and there were no significant changes between measurements.

In three normotensive subjects, renal venous blood was collected from both kidneys simultaneously. There was no significant difference in renin activity between them, either in the control or hypotensive periods.

Effect of reduction of arterial pressure on renin substrate activity of plasma and on renal plasma flow in normotensive subjects. In five subjects, renin substrate activity of renal venous plasma was measured at the same time, using human renin solution. The plasma substrate activity was $623 \pm 61$ (SE) $\mathrm{ng}$ per $\mathrm{ml}$ in the control period and $614 \pm 65$ in the hypotensive period; there was no significant change during reduction in pressure.

In four subjects, total renal plasma flow (RPF) was measured simultaneously by the Fick principle, using $p$-aminohippurate. When average mean arterial pressure was reduced from 93 to $65 \mathrm{~mm} \mathrm{Hg}, \mathrm{RPF}$ decreased from $653 \pm 66$ (SE) to $500 \pm 82 \mathrm{ml}$ per minute, and renal-systemic difference of renin activity ( $\triangle \mathrm{RA}$ ) increased from $2.8 \pm 1.0$ to $24.5 \pm 7.8 \mathrm{ng}$ per ml (Table III). $\Delta \mathrm{RA} \times \mathrm{RPF}$ was then calculated as an index of the amount of renin released from the kidney. It increased from $1.64 \pm 0.59$ ( $\mathrm{SE}$ ) to $10.38 \pm 3.06$ $\mu \mathrm{g}$ per minute during the hypotensive period; the increase was significant $(\mathrm{p}<0.05$, Table III).

Correlation between renin activity of renal venous plasma and mean arterial pressure level during reduction in pressure. Renin activity of renal 
TABLE III

Effect of reduction of arterial pressure on renal-systemic difference of renin activity and renal plasma flow in four normotensive subjects*

\begin{tabular}{|c|c|c|c|c|c|c|c|c|c|c|}
\hline \multirow[b]{2}{*}{ Subject } & \multicolumn{2}{|c|}{$\begin{array}{l}\text { Systolic and } \\
\text { diastolic BP }\end{array}$} & \multicolumn{2}{|c|}{ MAP } & \multicolumn{2}{|c|}{$\begin{array}{l}\text { Renal-systemic } \\
\text { difference of } \\
\text { RA }(\Delta \text { RA })\end{array}$} & \multicolumn{2}{|c|}{ RPF } & \multicolumn{2}{|c|}{$\Delta \mathrm{RA} \times \mathrm{RPF}$} \\
\hline & Control & Exp. & Control & Exp. & Control & Exp. & Control & $\overline{\text { Exp. }}$ & Control & Exp. \\
\hline & \multicolumn{2}{|c|}{$m m H g$} & \multicolumn{2}{|c|}{$m m \mathrm{Hg}$} & \multicolumn{2}{|c|}{$n g / m l$} & \multicolumn{2}{|c|}{$\mathrm{ml} / \min$} & \multicolumn{2}{|c|}{$\mu g / \min$} \\
\hline $\begin{array}{l}\text { K.G. } \\
\text { K.I. } \\
\text { T.M. } \\
\text { A.H. }\end{array}$ & $\begin{array}{l}122 / 78 \\
136 / 72 \\
111 / 70 \\
132 / 84\end{array}$ & $\begin{array}{r}84 / 48 \\
104 / 51 \\
91 / 56 \\
82 / 54\end{array}$ & $\begin{array}{r}93 \\
93 \\
84 \\
100\end{array}$ & $\begin{array}{l}60 \\
69 \\
68 \\
63\end{array}$ & $\begin{array}{l}5 \\
3 \\
0 \\
3\end{array}$ & $\begin{array}{r}37 \\
33 \\
2 \\
26\end{array}$ & $\begin{array}{l}547 \\
736 \\
795 \\
532\end{array}$ & $\begin{array}{l}396 \\
431 \\
745 \\
429\end{array}$ & $\begin{array}{l}2.74 \\
2.21 \\
0 \\
1.60\end{array}$ & $\begin{array}{r}14.65 \\
14.22 \\
1.49 \\
11.15\end{array}$ \\
\hline $\begin{array}{l}\text { Mean } \\
\text { SE } \\
\text { p }\end{array}$ & $125 / 76$ & $90 / 52$ & $\begin{array}{c}93 \\
\pm 3.3\end{array}$ & $\begin{array}{c}65 \\
\pm 2.1\end{array}$ & $\begin{array}{r}2.8 \\
\pm 1.0\end{array}$ & $\begin{array}{r}24.5 \\
\pm 7.8\end{array}$ & $\begin{array}{r}653 \\
\pm 66\end{array}$ & $\begin{array}{r}500 \\
\pm 82\end{array}$ & $\begin{array}{r}1.64 \\
\pm 0.59 \\
<\end{array}$ & $\begin{array}{r}10.38 \\
\pm 3.06 \\
5\end{array}$ \\
\hline
\end{tabular}

* Abbreviations: $\mathrm{MAP}=$ mean arterial pressure $; \mathrm{RA}=$ renin activity $; \mathrm{RPF}=$ renal plasma flow measured by the Fick principle.

venous plasma usually increased progressively parallel to progressive decrease in pressure. Renin activity observed during 27 hypotensive periods in 13 normotensive subjects, expressed in terms of logarithms, showed a significant correlation with the decrement of mean arterial pressure $(r=0.63, p<0.001)$ or with the degree of reduction in pressure expressed in terms of $\triangle \mathrm{MAP} /$ MAP ( $\mathrm{r}=0.69, \mathrm{p}<0.001)$; a significant increase in renin activity occurred when mean arterial pressure was reduced by more than $18 \mathrm{~mm} \mathrm{Hg}$ or

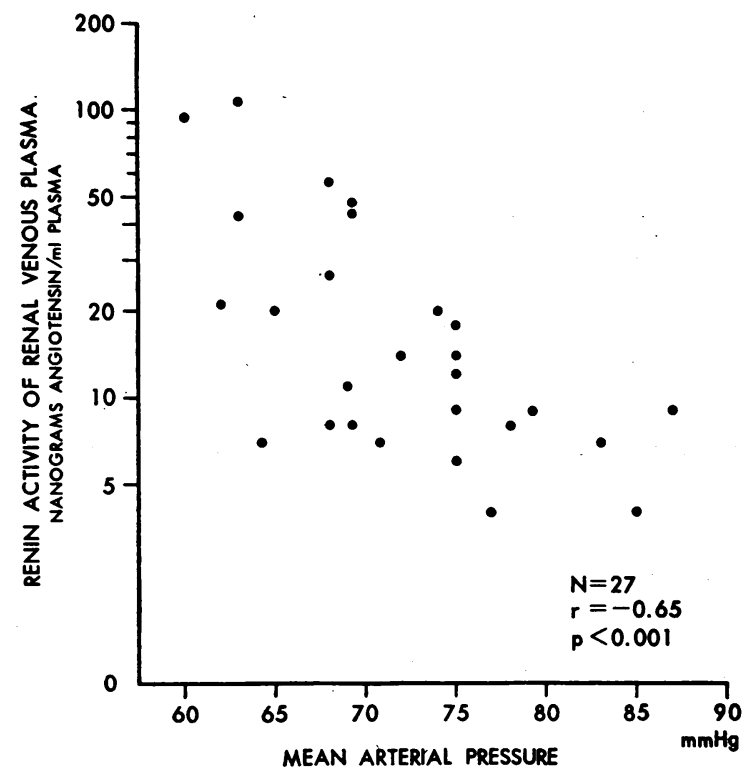

Fig. 5. Relationship Between Level OF MEAN ARTERIAL PRESSURE AND RENIN ACTIVITY OF RENAL VENOUS PLASMA IN LOGARITHMS, MEASURED DURING REDUCTION IN PRESSURE IN 13 NORMOTENSIVE SUBJECTS. by $20 \%$. There was also a significant reciprocal correlation $(\mathrm{r}=-0.65, \mathrm{p}<0.001)$ between renin activity in logarithms and the level of mean arterial pressure during the hypotensive period, as shown in Figure 5; an increase in renin activity became significant when mean arterial pressure was reduced to below a level of 70 to 75 $\mathrm{mm} \mathrm{Hg}$. In the control period, however, renin activity showed little correlation with mean arterial pressure levels. There were no correlations between renin activity and pulse pressure in the control or hypotensive periods.

Effect of reduction of arterial pressure on renin activity in plasma from the involved kidneys of renovascular hypertensive patients. Reduction of mean arterial pressure by from 11 to $55 \mathrm{~mm} \mathrm{Hg}$ by sodium nitroprusside infusion caused significant increase of renin activity in plasma from the involved kidneys in all renovascular hypertensive patients tested, and there was a marked increase in the renal-systemic difference (Table IV). Figure 6 illustrates an example. On the average, in 10 patients, renin activity of renal and systemic venous plasmas increased from 40.4 to 171 ( $p<$ $0.005)$ and 21.7 to $69.6 \mathrm{ng}$ per $\mathrm{ml}(\mathrm{p}<0.025)$, respectively, and the renal-systemic difference increased from 18.7 to $101 \mathrm{ng}$ per $\mathrm{ml}(\mathrm{p}<0.005$, Table IV). In 4 of the 10 patients, renin substrate activity of plasma from the involved kidney was measured at the same time. The plasma substrate activity was $610 \pm 26$ (SE) $\mathrm{ng}$ per $\mathrm{ml}$ in the control period and $590 \pm 34$ during reduction in pressure; there was no significant change.

In renovascular hypertensive patients, levels of 
TABLE IV

Effect of reduction of arterial pressure on renin activity of renal and.

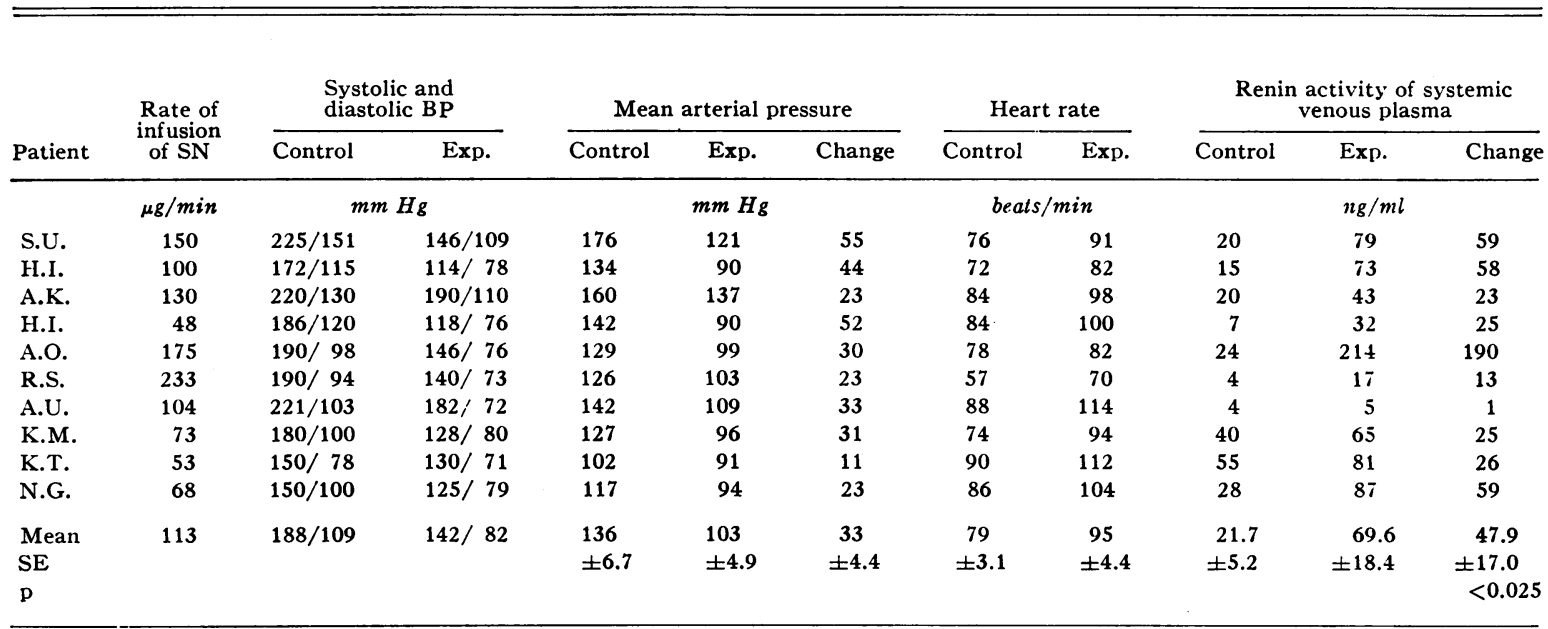

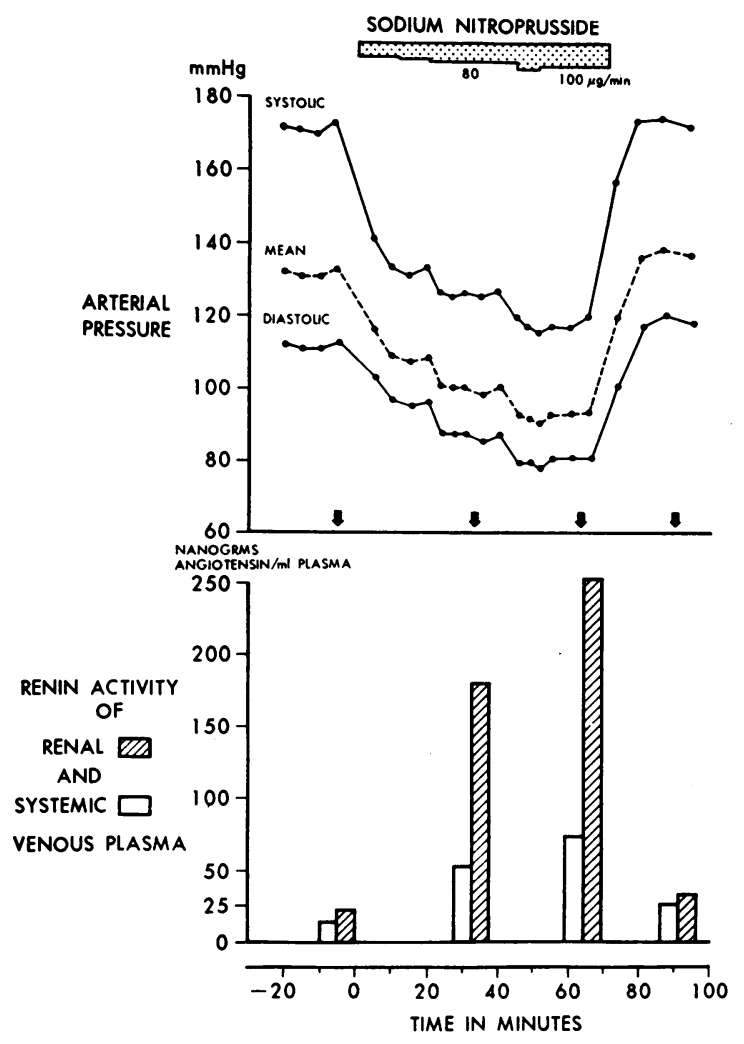

Fig. 6. EFFECT OF REDUCTION OF ARTERIAL PRESSURE ON RENIN ACTIVITY OF RIGHT RENAL VENOUS AND SYSTEMIC VENOUS PLASMA IN A 23-YEAR-OLD RENOVASCULAR HYPERTENSIVE PATIENT. The patient had severe stenosis of the right main renal artery. Marked increase in renin activity occurred at a mean arterial pressure of $100 \mathrm{~mm} \mathrm{Hg}$. mean arterial pressure at which increase in renin activity of renal venous plasma was detected were much higher than in normotensive subjects; renin activity increased significantly at pressures ranging from 90 to $137 \mathrm{~mm} \mathrm{Hg}$. Furthermore, when 10 renovascular hypertensive patients were compared with 8 normotensive subjects who showed significant increase in renin activity in renal venous plasma after reduction of arterial pressure, the magnitude of increase in renin activity of renal venous plasma and that of renal-systemic difference of renin activity were significantly greater in the renovascular hypertensive group than in the normotensive group. However, the decrement in pressure or the degree of reduction in pressure expressed in terms of $\triangle \mathrm{MAP} / \mathrm{MAP}$ was not significantly different between the two groups (Table V). The effect of reduction in pressure was unrelated to renin activity in the control period; in two patients, renin activity was in the normal range in the control period but increased significantly at mean pressures of 103 and $109 \mathrm{~mm}$ $\mathrm{Hg}$ (Table IV).

Renin activity in plasma from the uninvolved kidneys of renovascular hypertensive patients. In 7 of the 10 patients, renal venous blood was collected from both kidneys simultaneously. In the control period, renin activity of plasma from the uninvolved or less involved kidney was not significantly different from that of systemic venous plasma (Table IV). Six of the 7 patients had 
TABLE IV

systemic venous plasma in 10 patients with renovascular hypertension

\begin{tabular}{|c|c|c|c|c|c|c|c|c|c|c|c|}
\hline \multicolumn{6}{|c|}{ Involved kidney } & \multicolumn{6}{|c|}{ Uninvolved kidney } \\
\hline \multicolumn{3}{|c|}{$\begin{array}{l}\text { Renin activity of renal } \\
\text { venous plasma }\end{array}$} & \multicolumn{3}{|c|}{$\begin{array}{l}\text { Renal-systemic difference of } \\
\text { renin activity }\end{array}$} & \multicolumn{3}{|c|}{$\begin{array}{l}\text { Renin activity of renal } \\
\text { venous plasma }\end{array}$} & \multicolumn{3}{|c|}{$\begin{array}{c}\text { Renal-systemic difference } \\
\text { of renin activity }\end{array}$} \\
\hline Control & Exp. & Change & Control & Exp. & Change & Control & Exp. & Change & Control & Exp. & Change \\
\hline \multicolumn{3}{|c|}{$n g / m l$} & \multicolumn{3}{|c|}{$n g / m l$} & \multicolumn{3}{|c|}{$n g / m l$} & \multicolumn{3}{|c|}{$n g / m l$} \\
\hline 68 & 198 & 130 & 48 & 119 & 71 & & & & & & \\
\hline 23 & 252 & 229 & 8 & 179 & 171 & & & & & & \\
\hline 65 & 191 & 126 & 45 & 148 & 103 & & & & & & \\
\hline 34 & 64 & 30 & 27 & 32 & 5 & 5 & 12 & 7 & -2 & -20 & -18 \\
\hline 39 & 353 & 314 & 15 & 139 & 124 & 17 & 189 & 172 & -7 & -25 & -18 \\
\hline 6 & 162 & 156 & 2 & 145 & 143 & 5 & 23 & 18 & 1 & 6 & 5 \\
\hline 5 & 13 & 8 & 1 & 8 & 7 & 5 & 7 & 2 & 1 & 2 & 1 \\
\hline 55 & 121 & 66 & 15 & 56 & 41 & 40 & 70 & 30 & 0 & 5 & 5 \\
\hline 76 & 128 & 52 & 21 & 47 & 26 & 55 & 76 & 21 & 0 & -5 & -5 \\
\hline 33 & 228 & 195 & 5 & 141 & 136 & 28 & 91 & 63 & 0 & 4 & 4 \\
\hline 40.4 & 171 & 131 & 18.7 & 101 & 82.7 & 22.1 & 66.9 & 44.7 & -1.0 & -4.7 & -3.7 \\
\hline \pm 8.0 & \pm 30.7 & $\begin{array}{l} \pm 30.5 \\
<0.005\end{array}$ & \pm 5.3 & \pm 18.8 & $\begin{array}{l} \pm 19.2 \\
<0.005\end{array}$ & \pm 7.5 & \pm 24.0 & $\begin{array}{l} \pm 22.5 \\
\mathrm{NS}\end{array}$ & \pm 1.1 & \pm 4.8 & $\begin{array}{l} \pm 3.9 \\
\text { NS }\end{array}$ \\
\hline
\end{tabular}

unilateral renal arterial stenosis. When mean arterial pressure was reduced to 90 to $99 \mathrm{~mm} \mathrm{Hg}$, renin activity of plasma from the uninvolved kidney was not significantly different or less compared to that of systemic venous plasma. There was no significant change in the average renalsystemic difference of renin activity, whereas there was a marked increase in that in the involved kidney (Table IV). Figure 7 illustrates an example of the assay of renin activity of plasma from both kidneys in one patient with renovascular hypertension. Furthermore, the average renalsystemic difference during reduction in pressure was significantly $(p<0.05)$ less in the uninvolved kidney $(-4.7 \pm 4.8 \mathrm{ng}$ per $\mathrm{ml}$, Table IV) than that in the normotensive subjects $(20.1 \pm 7.4 \mathrm{ng}$ per $\mathrm{ml}$, Table II). One patient had severe stenosis of the left main renal artery and slight stenosis of the right artery. When pressure was reduced, renal-systemic difference in renin activity increased at $103 \mathrm{~mm} \mathrm{Hg}$ in plasma from the left side and at $95 \mathrm{~mm} \mathrm{Hg}$ in that from the right side.

\section{Discussion}

The results of the examinations of the assay method and the characteristics of the pressor material assayed seem to prove the validity of the present method for measurement of renin activity. Although the method does not measure the absolute concentration of renin in plasma, and other plasma constituents, including renin substrate (5), could affect renin activity measured by this method, it was useful for the purpose of the present study. Page, Dustan, and Bumpus (10) state that the comparison of renal venous with systemic plasma after incubation has proved reliable for comparable experimental purposes.

The results obtained in normotensive subjects

TABLE V

Degree of reduction of arterial pressure and magnitude of increase in renin activity during hypotensive period in normotensive subjects and in the involved kidney of renovascular hypertensive patients*

\begin{tabular}{|c|c|c|c|c|c|c|}
\hline & $\begin{array}{c}\text { No. } \\
\text { of } \\
\text { subjects }\end{array}$ & $\begin{array}{l}\text { MAP in } \\
\text { control } \\
\text { period }\end{array}$ & $\begin{array}{l}\text { Reduction } \\
\text { in MAP } \\
(\Delta \text { MAP) }\end{array}$ & $\triangle \mathrm{MAP} / \mathrm{MAP}$ & $\begin{array}{l}\text { Increase in RA } \\
\text { of renal venous } \\
\text { plasma }\end{array}$ & $\begin{array}{l}\text { Increase in } \\
\text { renal-systemic } \\
\text { difference of RA }\end{array}$ \\
\hline Normotensive & 8 & $\begin{array}{c}m m H_{g} \\
92 \pm 1.8\end{array}$ & $\begin{array}{c}m m H_{g} \\
26 \pm 2.4\end{array}$ & $27.8 \stackrel{\%}{ \pm} 2.3$ & $\begin{array}{c}n g / m l \\
45.6 \pm 11.1\end{array}$ & $\begin{array}{c}n g / m l \\
29.0 \pm 10.2\end{array}$ \\
\hline $\begin{array}{l}\text { Renovascular } \\
\text { hypertensive }\end{array}$ & 10 & $136 \pm 6.7$ & $33 \pm 4.4$ & $23.5 \pm 2.6$ & $131 \pm 30.5$ & $82.7 \pm 19.2$ \\
\hline $\begin{array}{l}\text { Significance } \\
\text { of difference }\end{array}$ & & & NS & NS & $\mathrm{p}<0.05$ & $\mathrm{p}<0.05$ \\
\hline
\end{tabular}

* Values given refer to means \pm standard errors. 


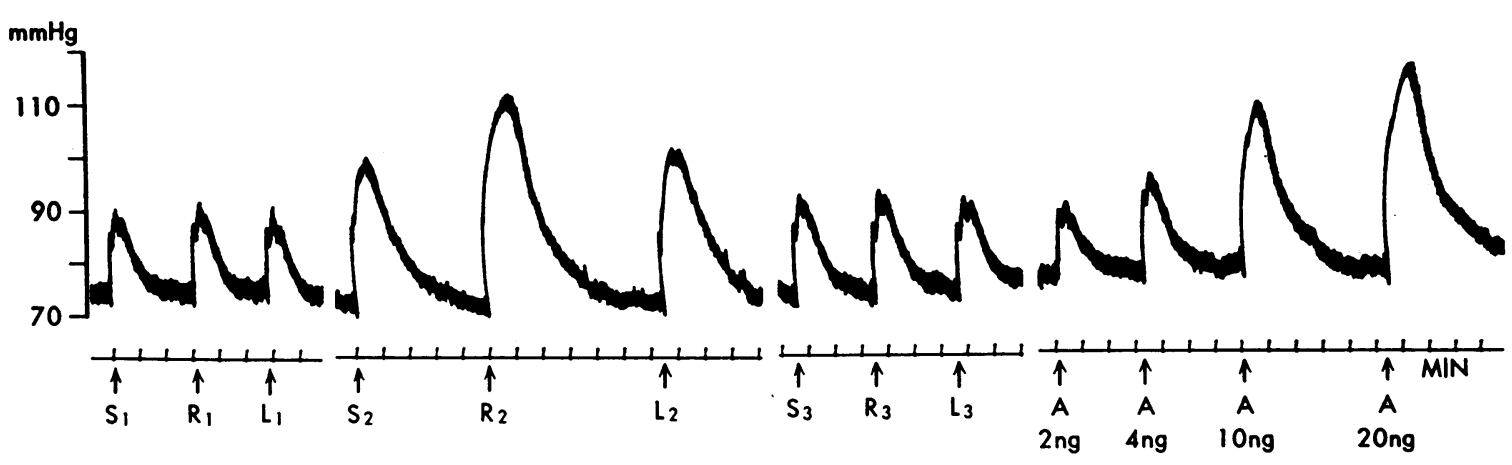

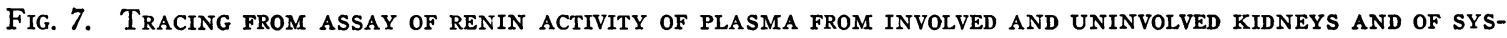
TEMIC veNOUS PLASMa IN A 19-YeAR-OLd RENOVASCULAR HYPERTENSIVE PATIENT. The patient had severe stenosis of the right main renal artery. The left artery was not affected. $S, R$, and $L$ indicate incubated systemic venous plasma and right and left renal venous plasma ( $0.2 \mathrm{ml}$ of the supernatant). 1, 2, and 3 represent samples collected during the control period, 20 minutes after reduction of mean arterial pressure from 117 to $94 \mathrm{~mm} \mathrm{Hg}$, and $15 \mathrm{minutes}$ after recovery of pressure, respectively.

are consistent with the observations of Skinner and associates in dogs (1). Acute reduction of arterial pressure caused significant increase in renin activity of renal venous plasma and in the renal-systemic difference of renin activity. Since there was no significant change in renin substrate activity of plasma measured at the same time, and since it has been reported that there is little difference in renin activity between systemic arterial and venous plasma (11), the products of the renal-systemic difference of renin activity and RPF were assumed to represent indexes of the amount of renin released from the kidney, although the products may give a minimal estimate of the true renal secretion of renin, since it has been known that renin leaks out also in the renal lymphatics (12) and urine (13). There was a significant increase in the calculated products parallel to inincrease in renin activity. Accordingly, marked increase in renin activity of renal venous plasma or in the renal-systemic difference of renin activity during reduction in pressure appears to indicate an increase in renin secretion from the kidney. The results suggest that the human kidney acts as a baroreceptor, in the sense that it can respond to change in arterial pressure by altering the rate of renin secretion; they support the view that this function of the kidney controlling renin secretion could be a homeostatic mechanism which participates in control of normal arterial pressure (1). This sensing mechanism seems capable of responding to reduction in pressure in a quantitative manner; renin activity of renal venous plasma, expressed in logarithms, showed a significant correlation with the degree of reduction in pressure and also with the level of mean arterial pressure. An increase in renin release became significant when mean arterial pressure was reduced to below a level of 70 to $75 \mathrm{~mm} \mathrm{Hg}$, whereas, above $75 \mathrm{~mm} \mathrm{Hg}$, there was no significant change. The findings suggest a threshold for increased secretion of renin at a mean arterial pressure level of 70 to $75 \mathrm{~mm} \mathrm{Hg}$ in normotensive subjects.

The present study does not clarify what final mechanism initiates increased secretion of renin when arterial pressure decreases, but there are at least three possibilities. 1) Decrease in mean renal perfusion pressure may directly stimulate the juxtaglomerular cells acting as baroreceptors $(14,1)$. A significant correlation between renin activity of renal venous plasma and the degree of reduction in pressure might support this theory, but there was no evidence which suggested that reduction in pressure acted directly. 2) Decrease in tubular sodium concentration or other change in tubular fluid caused by decrease in renal blood flow and glomerular filtration rate due to reduction in pressure may stimulate the macula densa and the juxtaglomerular cells (15). 3) Increased sympathetic discharge caused reflexly by reduction in pressure may exert a direct effect on the juxtaglomerular cells or an indirect effect on renal hemodynamics, resulting in increased secretion of renin. Stimulation of the renal nerve has been shown to cause increased release of renin in 
dogs (16). Increased sympathetic discharge during reduction in pressure was apparent from an increase in heart rate $(17)$; the average heart rate increased from 75 to 96 beats per minute during the hypotensive period (Table II). On the other hand, a threshold of 70 to $75 \mathrm{~mm} \mathrm{Hg}$ demonstrated in normotensive subjects is near the level under which renal autoregulation is known to fail, and this failure might be associated with an increased secretion of renin.

The differences in response between the kidneys of normotensive subjects and the involved kidneys of renovascular hypertensive patients were striking. In renovascular hypertensive patients, significant increase in renin activity of renal venous plasma and the renal-systemic difference of renin activity occurred in the involved kidney at mean arterial pressures ranging from 90 to $137 \mathrm{~mm} \mathrm{Hg}$. Although blood flow of the involved kidney was not measured, marked increase in the renal-systemic difference appears to indicate an increase in renin release from the involved kidney, since there was concomitantly a marked increase in renin activity in systemic plasma in 9 of the 10 patients (Table IV) and there was no significant change in renin substrate activity of plasma. The findings, then, suggest that the threshold of arterial pressure for increased renin release in the involved kidney was shifted to a range much higher than in normotensive subjects. Also, the magnitude of renin release from the involved kidney was significantly greater compared to that in normotensive subjects, whereas the decrement in pressure or the degree of reduction in pressure in terms of $\triangle \mathrm{MAP} / \mathrm{MAP}$ was not significantly different. In one patient (A.U.), the magnitude of renin release was considerably less than in other patients (Table IV) ; this might have been associated with the segmental ischemia of this patient's kidney (Table I).

The finding that, in the involved kidneys of renovascular hypertensive patients, the mechanism controlling renin secretion operates at much higher systemic arterial pressure levels with more enhanced responsiveness than in normotensive subjects appears to suggest that the renin-angiotensin system participates in maintaining high arterial pressure in this disease. The altered response of the involved kidney could tend to oppose a fall of systemic arterial pressure to normotensive levels. However, the participation of the renin- angiotensin system in this disease is not due to its direct vasoconstrictor action alone. Circulating renin levels in renovascular hypertensive patients have been reported to be variable (18-20) and were unrelated to levels of arterial pressure; renin activity of systemic venous plasma was in the normal range in three patients, whereas arterial pressures measured at the same time were hypertensive (Table IV).

The upward shift of the threshold of systemic arterial pressure at which renin release increased in renovascular hypertension does not imply resetting of the sensitivity of the renal mechanism that controls release, since renal perfusion pressure beyond the renal arterial stenosis could be much lower than systemic arterial pressure (21), and the renal arterial pressure sensed by the mechanism could be the pressure level at which renin release normally increases. Skinner and co-workers (2) found, in dogs made hypertensive by constriction of a renal artery, that renin release occurred at elevated systemic arterial pressure, but actual renal perfusion pressure beyond the constriction was in the same range as in normal dogs. The enhanced responsiveness of the involved kidney might also be explained by the pressure drop across the stenosis of the renal artery. The magnitude of renin secretion was shown to be correlated with the degree of reduction in pressure, and Figure 5 shows, at lower pressure levels, reduction in pressure of the same degree could cause secretion of more renin than at higher pressure levels.

The involved kidney, even when renin activity in the control period was normal, could cause significant increase in renin release at higher than normal pressure when arterial pressure was reduced. The finding that the effect of pressure reduction was unrelated to renin activity in the control period suggests that it may be preferable, for diagnosis of renovascular hypertension, to measure the threshold at which there is an increase in renin activity.

In the contralateral uninvolved kidneys of renovascular hypertensive patients, no significant release of renin was detected in the control or hypotensive periods; the renal-systemic difference of renin activity during reduction in pressure was significantly less, even when compared to that in normotensive subjects.

The mechanism of the different response of the 
uninvolved kidney was not known, but three possibilities exist. 1) Reduction in pressure to levels of 90 to $99 \mathrm{~mm} \mathrm{Hg}$ may not have reached the threshold for renin release. 2) The renin content of the uninvolved kidney may have been reduced to the extent that no renin was available. It has been shown, in rats (22) and dogs (23) made hypertensive by unilateral renal arterial constriction, that the renin content of the untouched contralateral kidney is markedly reduced compared to that in the normal kidney. 3) Large amounts of circulating renin and angiotensin released from the involved kidney may have exerted an inhibitory effect on renin secretion from the uninvolved kidney through a negative feedback mechanism. The infusion of angiotensin is known to suppress renin secretion in dogs (24) and plasma renin activity in man (25). In two renovascular hypertensive patients, renin activity of plasma from the uninvolved kidney was less than that of systemic venous plasma during reduction in pressure. This was unexplainable, but the leakage of renin into the renal lymphatics and urine may have been responsible.

\section{Acknowledgment}

We wish to express our appreciation to Dr. James W. $\mathrm{McCubbin}$ for his encouragement and valuable advice.

\section{References}

1. Skinner, S. L., J. W. McCubbin, and I. H. Page. Control of renin secretion. Circulat. Res. 1964, 15, 64.

2. Skinner, S. L., J. W. McCubbin, and I. H. Page. Renal baroreceptor control of acute renin release in normotensive, nephrogenic and neurogenic hypertensive dogs. Circulat. Res. 1964, 15, 522.

3. Page, I. H., A. C. Corcoran, H. P. Dustan, and T. Koppanyi. Cardiovascular actions of sodium nitroprusside in animals and hypertensive patients. Circulation 1955, 11, 188.

4. Helmer, O. M., and W. E. Judson. The quantitative determination of renin in the plasma of patients with arterial hypertension. Circulation 1963, 27, 1050 .

5. Pickens, P. T., F. M. Bumpus, A. M. Lloyd, R. R. Smeby, and I. H. Page. Measurement of renin activity in human plasma. Circulat. Res. 1965, 17, 438.

6. Khairallah, P. A., F. M. Bumpus, I. H. Page, and R. R. Smeby. Angiotensinase with a high degree of specificity in plasma and red cells. Science 1963, 140,672 .
7. Lever, A. F., J. I. S. Robertson, and M. Tree. The estimation of renin in plasma by an enzyme kinetic technique. Biochem. J. 1964, 91, 346.

8. Haas, E., and H. Goldblatt. Renin content of kidneys in experimental renal and human essential hypertension. Amer. J. Physiol. 1959, 197, 1103.

9. Snedecor, G. W. Statistical Methods, 5th ed. Ames, Iowa, Iowa State University Press, 1956.

10. Page, I. H., H. P. Dustan, and F. M. Bumpus. A commentary on the measurement of renin and angiotensin. Circulation 1965, 32, 513.

11. Helmer, O. M. The renin-angiotensin system and its relation to hypertension. Progr. cardiovasc. Dis. 1965, 8, 117.

12. Lever, A. F., and W. S. Peart. Renin and angiotensin-like activity in renal lymph. J. Physiol. (Lond.) 1962, 160, 548.

13. Brown, J. J., D. L. Davies, A. F. Lever, A. M. Lloyd, J. I. S. Robertson, and M. Tree. A reninlike enzyme in normal human urine. Lancet 1964, 2, 709.

14. Tobian, L. Interrelationship of electrolytes, juxtaglomerular cells and hypertension. Physiol. Rev. 1960, 40, 280.

15. Vander, A. J., and R. Miller. Control of renin secretion in the anesthetized dog. Amer. J. Physiol. 1964, 207, 537.

16. Vander, A. J. Effect of catecholamines and the renal nerves on renin secretion in anesthetized dogs. Amer. J. Physiol. 1965, 209, 659.

17. Glick, G., and E. Braunwald. Relative roles of the sympathetic and parasympathetic nervous systems in the reflex control of heart rate. Circulat. Res. $1965,16,363$.

18. Helmer, O. M. Renin activity in blood from patients with hypertension. Canad. med. Ass. J. 1964, 90, 221.

19. Brown, J. J., D. L. Davies, A. F. Lever, and J. I. S. Robertson. Plasma renin concentration in human hypertension. II. Renin in relation to aetiology. Brit. med. J. 1965, 2, 1215.

20. Pickens, P. T., H. P. Dustan, F. M. Bumpus, and I. H. Page. Measurement of plasma renin activity in hypertension. Hypertension 1965, 13, 90.

21. Carter, S. A., and C. W. Ritchie. Measurement of renal artery pressures by catheterization in patients with and without renal artery stenosis. Circulation 1966, 33, 443.

22. Gross, F., and P. Lichtlen. Pressor substances in kidneys of renal hypertensive rats with and without adrenals. Proc. Soc. exp. Biol. (N. Y.) 1958, 98, 341.

23. Haas, E., and H. Goldblatt. Studies on renin. Biochem. Z. 1963, 338, 164.

24. Vander, A. J., and G. W. Geelhoed. Inhibition of renin secretion by angiotensin II. Proc. Soc. exp. Biol. (N. Y.) 1965, 120, 399.

25. De Champlain, J., J. Genest, R. Veyrat, and R. Boucher. Factors controlling renin in man. Arch. intern. Med. 1966, 117, 355. 